\title{
Social Perception of Infertility and Its Treatment in Late Medieval Italy: Margherita Datini, an Italian Merchant's Wife
}

NAM, Jong Kuk*

I. Introduction

II. Social View of Margherita's Infertility

III. Various Ways of Treating Infertility

IV. Conclusion

\section{Introduction}

Infertility, which hinders reproduction, has always been a critical social issue. ${ }^{1)}$ In particular, in a traditional society in which death rates were high and the society itself periodically suffered from acute population decrease, this issue was a problem which imperiled a family's permanence and posed a threat to the existence of a community. In most, if not all, past societies, women were blamed for infertility. Such women were stigmatized as being defective and had to endure all kinds of social criticism and disadvantages

\footnotetext{
* Department of History, Ewha Womans University

E-mail: namjk0513@ewha.ac.kr

1) This article builds on excellent research done by several other scholars. In recent decades, infertility in Medieval Europe has received historical attention from many scholars (Bologne, 1988; Cadden, 1993; Lindgren, 2005; Monica Green, 2008; Geaman, 2013; Oren-Magidor, 2015; Oren-Magidor and Rider, 2016; Rider, 2016).
} 
NAM, Jong Kuk : Social Perception of Infertility and Its Treatment in Late Medieval Italy: Margherita Datini, an Italian Merchant's Wife.

(Taylor, 2006:89).

Infertility was a huge problem in late medieval Europe, which had a high infant mortality rate. When women were unable to have a child, their lord would take some of their inheritance; ${ }^{2)}$ some women even received a notification nullifying their marriage with their husband, which was a very extreme decision. ${ }^{3)}$ Muriel, a Jewish woman who lived in England in 1240, was asked by her husband David to cancel her marriage. She refused to do so and appealed to the court of Jewish rabbis (Goldy, 2008: 134).

However, infertility could not be solved by harshly criticizing infertile women and imposing social sanctions on them. This disaster had to be explained and required fundamental solutions. Although many societies viewed women as the cause of the problem, approaches to the issue varied according to an individual society's characteristics. What were the typical 'medieval,' 'Christian,' and 'European' solutions?

Medieval European churches were not unanimous in their interpretations and explanations of infertility. During the Hebrew Antiquity, inexplicable infertility was generally considered to be a curse from God (Bologne, 1988: 213-215). On the other hand, some early medieval churches taught that infertility was a trial to be borne, stating that a long period of sterility could be a sign, not of malediction, but of particular grace obtainable after repeated

2) In the 12th century, Ramon de Ribes, a lord of Barcelona, confiscated all the property of a woman farmer who died without a child for the reason of her infertility(Taylor, 2006: 88-89).

3) At that time, there was a controversy over whether or not it is right for a woman with infertility to get married. In the 12th century, Gratian argued that infertility was a fair reason for marriage nullity. In addition, according to Christian doctrine, when sexual intercourse is impossible since men are frigid or impotent, a divorce could be cancelled. Besides, in the ninth century, Igmarus, the Archbishop of Reims, said that when witches with the help of devils prevent married couples from having sexual relations by using evil maleficium, a divorce can be nullified (Noonan, 1965: 289; Goldy, 2008:134). 
NAM, Jong Kuk : Social Perception of Infertility and Its Treatment in Late Medieval Italy: Margherita Datini, an Italian Merchant's Wife.

prayer (Oren-Magidor, 2015: 97-102). But, there existed the unreasonable perception that infertility was a curse from God, while childbearing was a blessing. In addition, it was widely believed that the devil and witchcraft caused infertility and sexual dysfunction (Evans, 2012: 1-2). A famous preacher in the 15th century, Jean Raulin, said that the devil and witches impeded generation, citing seven causes of infertility. ${ }^{4)}$ As shown in "The Malleus Maleficarum," a text from the 15th century, some theologians and canonists believed that the devil could keep men and women from having a child in various ways, and they often criticized infertile women as witches (Kramer and Sprenger, 1971: 54-56). Even in seventeenth-century England, Samuel Hieron suggested in his book that barrenness was a form of punishment for sins (Oren-Magidor, 2015: 91). On the contrary, most educated doctors believed that infertility was triggered by different causes and that it was a treatable disease. Even some clerics shared the reasonable belief that sterility was a sort of disease requiring medical treatment, and often argued for the possibility of male infertility, contradicting the common assumption that women were generally responsible for infertility (Rider, 2016: 1).

As discussed above, there were conflicting opinions in medieval Europe, so it is very difficult to pinpoint society's average perception of infertility. In addition, it is not easy to understand specifically what social criticisms and disadvantages infertile women had to endure in medieval Europe, since there are almost no extant records. It is very rare that women in general in medieval Europe kept records, and especially so for those who were infertile. This is even the case for noble-women, because reading

4) Seven causes are for the glory of God, for human humility, for augmenting grace in marriage, for saluting marriage, excess of sex, witchcraft (Bologne, 1988: 213-215). 
NAM, Jong Kuk : Social Perception of Infertility and Its Treatment in Late Medieval Italy: Margherita Datini, an Italian Merchant's Wife.

and writing were not their usual activities and were often criticized as very disrespectful behavior. For this reason, existing studies on medieval women rely heavily on theoretical treatises or prescriptive essays written by clerics (Byrne, 1996:5).

Fortunately, one infertile woman left a lot of records. She was Margherita, the wife of Francesco di Marco Datini, a merchant from Prato; she lived in Italy in the late 14 th century. Her life illustrates the social criticism, discrimination, and agony that infertile women had to suffer from in the late Middle Ages in Europe. ${ }^{5)}$ Before talking about the main subject in earnest, we must briefly look at Margherita's life. She was born in a noble family in Florence. She married 41 year-old Francesco Datini when she was 16 years old in the year 1376, in Avignon. Francesco was from Prato, near Florence, and was a merchant who earned a great deal of money in business as a young man. The reason why she, a noble-woman, married a commoner was that her family were living in exile and were poor after having been expelled from their hometown following her father's execution owing to political strife in Florence. She, a member of the noble class, provided her husband youth and prestige, and Francesco, a bourgeois merchant, gave his wife a lavish lifestyle. Perhaps for this reason, he did not receive a dowry from his wife's family. ${ }^{6}$

The Datinis' marriage was not always good. Margherita suffered from infertility, which was a lifelong problem that haunted them. This was a serious source of trouble, and it worsened their conjugal relationship

5) While Margherita's infertility is well known by some scholars, its detailed history has remained under-studied (Park, 1998: 129-149; Park, 1985; Origo, 1986); James, 2010: 53-72).

6) Her father who was involved in political strife in Florence was convicted of treason and executed in 1360 (Schuller, 2013: 303). 
NAM, Jong Kuk : Social Perception of Infertility and Its Treatment in Late Medieval Italy: Margherita Datini, an Italian Merchant's Wife.

(James, 2010: 56). In addition, whether because of either her infertility or his business, they lived separately for 26 years. Thanks to this set of circumstances, we have been left with precious historical materials from the Middle Ages. We have 244 letters that were written from Margherita to Francesco, and 181 from Francesco to Margherita, from 1385 to 1410. A total of 425 letters were preserved (Crabb, 2015: 2). However, Margherita rarely wrote about her infertility. Rather, infertility was more often discussed in letters between her husband and others.

This study aims to identify the general perception held by ordinary European people regarding infertility by focusing on the Datini documents. Analysis of medieval medical texts is also invaluable in figuring out more about the general attitudes and perception of European society about infertility (Cartelle, 1993; Parrado, Cartelle and Ingelmo, 1999; Cartelle and Ingelmo, 2003: 25, 85-97; Green, 2001; Anglicus,1516; Constantinus, 1983). By looking at the ways in which medical doctors diagnosed infertility and prescribed treatments for it, the issue can be understood in a more comprehensive and balanced way. We hope to reach a clear understanding of where the attitudes towards infertility held by ordinary people fell on the spectrum from the extremely unreasonable explanation of infertility as a religious malediction to the rational medical idea of infertility as a disease to be treated by medical practitioners.

\section{Social View of Margherita's Infertility}

It is known that in medieval European society, Christianity had an extremely broad impact. Its reach extended to the infertility issue, too (Morice, 1995: 498; Austriaco, 2011). Because of the teaching, "Be fruitful, 
NAM, Jong Kuk : Social Perception of Infertility and Its Treatment in Late Medieval Italy: Margherita Datini, an Italian Merchant's Wife.

and multiply, and replenish the earth" in Genesis, fecundity was often understood as a blessing and, conversely, infertility was thought of as a punishment or curse made by God. ${ }^{7)}$ Although God used infertility as a punishment only once in the Old Testament (Lunenfeld and Elder, 2005: 129-31), medieval churches preached that infertility was a punishment for sin. For example, Thomas Aquinas described infertility as evil (malum) and said that it is God's punishment. He believed that the result of violating the sacred compact of marriage was infertility, and also thought that sacrilege and adultery, etc. caused infertility (Morice, 1995: 501; Echenverria, 2011: 286). The same is often found in Italian literature and artwork from the late Middle Ages. Hell and the Last Judgment became popular themes, and infertility was depicted as being related to sin. Because of this viewpoint, the Virgin Mary's womb was described as a tool of redemption, and infertility was described as diablerie (Noonan, 1965: 289; Longenbach, 2008: 15-16).

Some condemned infertility as the conduct of devils or witches. Theologians interpreted infertility as the result of a wicked plan hatched by devils. ${ }^{8)}$ In the 9th century, Hincmar, Archbishop of Reims, said that witches with the help of devils prevented married couples from having a child. In the twelfth century, Gratian and Peter the Lombard also put forth this view.9) Pierre of Palude, a French theologian who died in 1342,

7) Since Jehoiakim incurred God's anger, even if he had sons, they could not become a king under a curse (Rooy, 1986: 225; Morice, 1995: 498).

8) Theologians believed that it is possible to make people not have a child through potion or incantation (Goldy, 2008: 142; Park, 1998: 132-33).

9) Hincmar said that "if a marriage has been annulled on account of the impotence of the husband, he cannot marry again if his impotence was due to natural causes. If his condition, however, was the result of witchcraft and the marriage had been declared void after the customary treatments had failed, he was permitted to marry again. Peter the Lombard said that "De his qui maleficiis impediti coire non possum." (Marti-Ibaňez, 1960: 146; Gratian, 1959: decretum 2.33.1.4; Noonan, 1965: 289-30). 
NAM, Jong Kuk : Social Perception of Infertility and Its Treatment in Late Medieval Italy: Margherita Datini, an Italian Merchant's Wife.

contributed to the association of infertility with Satanism by listing five tricks done by devils that hinder pregnancy (Kramer and Sprenger, 1971: 54-56; Baldwin, 1994: 212). First, since devils have the ability to prevent bodies from approaching each other, devils can make it so that men and women are not physically close to each other. Second, devils can stimulate sexual desire or freeze it. Third, devils can make men hate women by confusing men's imaginations. Fourth, devils can make men not get an erection. Fifth, devils can block the flow of semen. Also, many other theologians believed that using an evil spell could keep people from having a child and criticized the casting of such spells as a sin (Noonan, 1965: 165, 289). The perception of infertility as diablerie was officially acknowledged by Pope Innocent VIII, who issued a papal bull in 1484 declaring that "they (devils male and female) hinder men from begetting and woman from conceiving, and prevent all consummation of marriage."

But the voices of the medieval churches were not unanimous in their view of infertility. Some clerics who were familiar with medical knowledge interpreted infertility not in extremely religious terms but in scientific or medical terms. For instance, Albertus Magus, a German Dominican friar in the late thirteenth century, who was known as a doctor, explained the nature and causes of infertility as follows: "Since there are many things which cause coitus, there must be many circumstances promoting and impeding generation, for whatever has a part in the causes also has a part in those causes' circumstances, which impede and promote operations." He suggested that the impediment to generation may stem from the man rather than the woman (Cadden, 1993: 239-240). Similarly, John of Mirfield, a cleric in late fourteenth century England, warned his readers of not only female but also male infertility, saying that "when sterility happens 
NAM, Jong Kuk : Social Perception of Infertility and Its Treatment in Late Medieval Italy: Margherita Datini, an Italian Merchant's Wife.

between married people, the males are accused by many people of not having suitable seed." (Rider, 2016: 1).

Since the perception and explanation of infertility by churches in the Middle Ages ranged from it being a curse from God or a wicked act of the devil to it being the result of both female and male physical defects, it is difficult to determine the common social perception and attitudes towards infertility. We ask how ordinary people, including Margherita Datini and her husband, comprehended and overcame the problem of infertility.

Francesco's relatives in his hometown and his business associates started to worry about Margherita's infertility after the couple had been married for several years and had not had a child. When the Datinis were in Avignon, the people who most often talked to Francesco about Margherita's infertility were Monte Angiolini and Niccolo Tecchini. Monte and Francesco seemed to have a relationship that went beyond just being business associates. Monte's letters refer to Francesco and Margherita as "godfather (compare)" and "godmother (comare)." Therefore, it seems that he was close enough to Francesco that they talked about their problems. In their letters, their promise to become each other's children's godfather, Francesco's feeling of disappointment at having no child, and treatment for Margherita's infertility, etc. were mentioned (James, 2010: 56).

Monte showed an active interest in the Datinis' infertility problem. If he saw infertility as diablerie, that would not be the case. In a letter dated 20 April 1380, he expressed sorrow for Margherita when telling the couple that his wife was pregnant. ${ }^{10)}$ In a letter dated 24 February 1382, he gave

10) (Che mon Margherita non sia grossa mi pesa/ sono certo e lla sa ora che la sua e vostra comare e grossa/ credo si di presso a sei mesi/ scrivete a vi volete io dira il battezi per noi/ essai penai mapure mi rabattemi al fatto. $>$ Francesco wrote a letter to Monte on January 21st, 1380 and Monte replied to the letter (Archivio di Stato di Prato, fondo di 
NAM, Jong Kuk : Social Perception of Infertility and Its Treatment in Late Medieval Italy: Margherita Datini, an Italian Merchant's Wife.

advice and reassurance by reminding the Datinis that he had spoken about the infertility problem many times. ${ }^{11)}$ If he thought that infertility was a punishment which should be criticized religiously, and if he believed that Margherita was a witch, he would not have taken such an interest. To Monte, this problem was a topic for casual conversation and there was no fear regarding the issue.

In addition, in a letter from 4 October 1379, there was even more intriguing content. He wrote to Francesco, "Please tell Margherita that we have done everything we could to become a good godfather and a good godmother and we will continue to do it (A monna Margherita direte che Io o fatto e fo mio potere efforzami che possiamo esse compari con effetto)." Here, by saying that they were doing their best to become a godfather and a godmother, he was urging Francesco to try harder. He pointed out that Francesco did not make as much effort as he did to have a child. He

Datini (thereafter ASP), busta 1090, codice 1402925; Crabb, 2005: 151).

11) (Monna ghostanza vi scrisse per Niccolo di Bonarcorso e mandovi per lui una scritta di mano di Pauolo Dandrea come el gli e contento che ghaggi siano nel compito de denare dovere ritendre per monna ghostanza/ pero che la compra dice che non sentende compare case terre ma sscrizie o cose siano in Vignone o ndel distretto ne fiol cccc che ac Francesco di Marco non so se sono specificati e ghaggi e dela norio I libro non gli date pero che nac la copia fece ser Lorenzo Buti/ ser Bartelo Apeno. A la parte dele fanciulle e lla va scritto piu volte e cosi disse a Niccolo. vi dicesse il tutto di loro rimettea in voi e cosi dice vuole faciare/ di quanto vedro sia a bisogno avisarvi dicio di tenpo in tenpo sil faro/ e di quanto sapero on manchera davisarvi.) (ASP, Datini, busta 1090, codice 1402938).

12) LA monna Margherita direte che Io o fatto e fo mio potere efforzami che possiamo esse compari con effetto/ voi e io ma forse il molino e guasto per non avere lacqua al modo usato/ ma forse quando sara ricostumato far frutto di buona farina/e come fosse per fustare/ I lui diro ma non di meno fatene voi vostro potere e potea essere prima il vostro molino chel mio fara buona farina si che faccendo voi e noi nostro potedere tosto ci aura chagione da essere compari con effetto. I Dio provedera il miglore come sta sempre. $>$ (ASP, Datini, busta 1090, codice 1402924, Monte Angiolini to Francesco, October 1394; Crabb, 2015: 15). 
NAM, Jong Kuk : Social Perception of Infertility and Its Treatment in Late Medieval Italy: Margherita Datini, an Italian Merchant's Wife.

blamed the husband for the couple's infertility. In his letter of 21 June 1381, he again blamed Francesco for his relative laziness, saying that he, Monte, had done everything possible to make his own wife pregnant. ${ }^{13)}$ However, in a letter dated 21 October 1380, he blamed Margherita for her laziness, since she did not take any efforts to have a child, unlike Francesco, who tried very hard to have a child. ${ }^{14)}$ However, the fact that Monte put some blame on Francesco is a sign that our notion that traditional society only blamed women for infertility may be a wrong one.

Margherita's brother-in-law, Niccolo Tecchini, also offered Francesco many tips about having a child. In a letter written 2 July 1381, Niccolo even proposed that if Margherita wanted, he would lend her one of his own children. In a letter written 19 August 1381, he stated that his wife, Francesca, wanted to send one or two of her sons to her sister, Margherita. ${ }^{15)}$ In a letter written on 28 February 1382, he said he hoped that Margherita would have a long-waited child. ${ }^{16)}$ In a letter dated 24 March 1382, he comforted Francesco, who was disappointed at being told so often that his wife was not pregnant. ${ }^{17)}$

13) LLa nostra comare o salutata per vostra parte/ io cercho coprato ella faccia qualche fanciullo del quale di nuovo siamp pu di fermo compari e per ancora non ci e I.) (ASP, Datini, Monte Angiolini to Francesco, 21 June 1381).

14) LLa vostra comare dicie voi prochacciate di fare de fanciulli che ella non nono velle piu fare/ e che sella per lasse a la comare consignerella come si fanno ma non cie il modo/ salvo uno ce voi costi prochacciate e noi qui prochacciaremo e chi prima lara si faccia come conponemo.〉 (ASP, Datini, busta 1090, codice 1402927; James, 2010: 56).

15) 〈Sella Margherita vole dalla Franciescha un de suoi fanciulli per abiare e gli altri acomume/ ella ne contenda $\rangle$. (ASP, Datini, busta 1103, codice 133344-133345. Letter from Niccolò dell'Ammannato to Francesco Datini).

16) 〈ma Io vorrei che lla ingrossasse e faciesse fanciulli che atendere---laria di qua e piu mutia chativa. A di XXI di questo mese fecie la Franciescha uno fanciullo $\rangle$. (ASP, Datini, busta 1103, codice 133347. Letter from Niccolò dell'Ammannato to Francesco Datini).

17) 〈Nella Margheria non avete voglia davere figliuoli〉. (ASP, Datini, busta 1103, codice 133348. Letter from Niccolò dell'Ammannato to Francesco Datini). 
NAM, Jong Kuk : Social Perception of Infertility and Its Treatment in Late Medieval Italy: Margherita Datini, an Italian Merchant's Wife.

As shown in the letters between the Datinis and their relatives, Margherita's infertility seemed to be of great interest. Margherita's infertility and severe cramps were casual conversation topics; not only her family and close relatives, but also business associates talked about such things, and they even suggested many ways to treat them. Nobody denounced her as a witch or cursed the couple, saying that they were being punished by God. This would not be the case if infertility was considered the result of $\sin$ and/or was a taboo topic. ${ }^{18)}$

Another fact that can be confirmed from these letters is that at that time, people believed that environmental and psychological factors play quite an important role in conceiving a child. Their relatives in Prato, their hometown, believed that it would provide a more suitable environment for the Datinis to have a child than Avignon, a faraway, foreign land. In 1380, Mrs. Piera, Francesco's stepmother, sent a letter to them telling them to come back to their hometown of Prato since they still did not have a child after several years of being married. "With God's grace, you will be able to have a child here. God allowed you to have wealth there in Avignon. Here, He will give you your family." In a letter sent to them six months later, she wrote, "If you come back here, the atmosphere will blow away your troubles. That is because pleasure helps pregnancy but troubles create an adverse effect." Margherita's sister and her husband gave Francesco and Margherita similar advice. They told the Datinis that the land of Prato is masculine and facilitates pregnancy. They also added that a couple who could not have a child in Genoa had a child as soon as they moved to

18) In the European society of the late Middle Ages, commoners as well as the royals tried to treat infertility. William II, King of England sought help from doctors from the University of Salerno to treat the infertility of Queen Joanna (1165-1299) (Green, 2008: 85-86). 
NAM, Jong Kuk : Social Perception of Infertility and Its Treatment in Late Medieval Italy: Margherita Datini, an Italian Merchant's Wife.

Tuscany (Origo, 1986: 165-67).

Monte also advised the Datinis that a good environment and stable atmosphere are advantageous to having a child. In his letter dated 20 April 1380, he gave the advice that the environment in Prato was more suitable for having a child than that in Avignon, and passed on the news that his wife got pregnant. ${ }^{19)}$ In his letter on 3 November 1380, he once again stressed that the environment of Prato was very conducive to having a child, but the environment of Avignon was not good. ${ }^{20)}$ On 24 March, he advised Margherita, his children's godmother, on the importance of environment. ${ }^{21)}$ In a letter dated 29 April 1382, he wrote that if Margherita came back to the hometown, his wife would hand down the secrets to having a child, and said that there was no woman who could not have a child in Prato (non ci e donna che non sia o grossa e imparto) (ASP, Datini, busta, codice 315535, Monte Angiolini to Francesco, 29 April 1382; Crabb, 2015:16).

However, not all people at that time looked at infertility from a rational and reasonable point of view without any religious prejudice. European Christians in the Middle Ages still understood infertility from a religious point of view. Many people, including the Datinis, believed that being able to have a child absolutely depends on the will of God. In particular, Francesco firmly believed that God would punish the bad behavior of men.

19) Francesco wrote a letter to Monte on January 21st, 1380 and Monte replied to the letter (ASP, Datini, busta 1090, codice 1402925; Crabb, 2005: 151).

20) 〈Forte impesa siate a Prato per lo modo mi scrivete pero ve troppo grande schocio e dicio non inposso avitare pero che come per laltra vi dissi noi siamo in tanto schandalo che non saremo dacordo a fare procura.) (ASP, Datini, Monte Angiolini to Francesco, 3 November 1380, busta 1090, codice 1402928).

21) (A la comare o detto qaunto dite di mostrare a la comare come si fanno I fanciulli, dice pensa proclia(?) dal Ghallo o dala Galina/ ma pure laria di qua ci fa figlare dovere di 50 anni e tutte ne fanno fame come gli racomamdatela a loi.) (ASP, Datini, busta 1090, codice 1402939). 
NAM, Jong Kuk : Social Perception of Infertility and Its Treatment in Late Medieval Italy: Margherita Datini, an Italian Merchant's Wife.

That was why he took care of many girls when he was in Avignon. He was afraid of God's punishment if he did not do so. Besides, he believed that the ability to conceive a child absolutely depends on God's will, and he was afraid that if he did not help other children, he could not have a child himself because God would punish him (Crabb, 2015: 14). In reality, most European Christians at that time, including the Datinis, believed that God manages all human life.

That is not the end of it. People at that time also thought of infertility in a superstitious and magical way. People orally passed on treatment methods, such as spells to kick out devils or prayers to God when taking medicine (Origo, 1986: 334). Margherita's sister Francesca suggested a similar treatment method. In this respect, professional doctors were no exception. They used both medication and magical thinking (Shatzmiller and Lavoie, 1984: 135).

Astrology interpreted infertility in its own way. European astrologists affected by Islamic astrology of the 12th to 13th centuries explained that movements of the heavenly bodies have an effect on pregnancy. According to Albuther's book, which was translated in Europe in the 13th century, Gemini, Leo, and Virgo were associated with infertility, and people who were born when Venus and the moon were located in those positions and when Mars and Saturn were located in bad positions could not have a child. Some astrologists said that the position of Venus affects men's sperm, and when it is located at either Leo or Scorpio, they cannot have a son. Giovanni Pontano, a humanist in Italy at the end of the 15th century, argued in his book, De rebus coelestibus, that Venus causes male infertility 
NAM, Jong Kuk : Social Perception of Infertility and Its Treatment in Late Medieval Italy: Margherita Datini, an Italian Merchant's Wife.

and some other stars cause female fertility. ${ }^{22)}$

So, people at that time understood infertility from various points of view. The social perception of infertility varied from stubborn medieval Christian thoughts, such as that it is the devil's work, to relatively reasonable and scientifically minded thoughts that the environment plays an important role in pregnancy. Nevertheless, the Datini documents show that ethical, religious, and social criticism on infertility was not strong in urban Italian society in the late Middle Ages. Many people thought of infertility as a disease to be medically treated. That is why people around the Datinis recommended a variety of ways to have a child over the course of 20 years. ${ }^{23)}$

Although the relatives and acquaintances of the Datinis did not consider Margherita's infertility as a sin and criticize it, Margherita must have suffered from it. In medieval European society, books concerned with morals and ethics taught that giving birth to a child and raising the child is a crucial responsibility of every woman. In particular, women in the upper-middle class were under a great deal of social pressure to have a son who would go on to inherit the family's wealth (Byrne and Congdon, 1999: 40; OrenMagidor, 2015: 86). Therefore, Margherita, too, must have been under emotional pressure to have a son to inherit her husband's wealth. Infertility itself was definitely the seed of conflict between Francesco and Margherita (Oren-Magidor, 2015: 86). The evidence that infertility burdened Margherita emotionally includes that she hated to mention her infertility directly in her letters. Actually, although the Datinis sent and received many letters on

22) Pontano said that physical features like extreme obesity, also, cause infertility (Lemay, 1982: 199).

23) At the age of 33 , she still sought ways to treat her infertility from people around her (Park, 1985: 59). 
NAM, Jong Kuk : Social Perception of Infertility and Its Treatment in Late Medieval Italy: Margherita Datini, an Italian Merchant' s Wife.

all kinds of topics, including family affairs, business, politics, and conjugal relations, they rarely mentioned infertility. Margherita mentioned the child issue only twice. In a letter dated 23 January, 1395, she told her husband not to be disappointed by the fact that they did not have a child. She asked her husband to think of infertility as their fate and not to complain after seeing her sister and her husband's grief over the loss of her sister's children (Margherita, 2012: 160-61; Crabb, 2015: 47). In a letter from 18 May, 1402, she comforted her husband Francesco saying, "God took the possibility of having a son.” (Margherita, 2012: 365-366).

\section{Various Ways of Treating Infertility}

The social perception of infertility can be confirmed in the ways in which it was treated. Just like there were many different perceptions on infertility, there were a variety of ways to treat it. Some treatments were full of religious madness, some included traditional folk remedies, and some used the medical knowledge available at that time. ${ }^{24)}$ Margherita and

24) Medicine in Western Europe of the Middle Ages borrowed a lot from Islamic medicine which inherited ancient Greek and Roman medical knowledge and developed it. Gynaecology in Western Europe of the Middle Ages was no exception. Actually, medical knowledge about infertility in Western Europe of the late medieval times was affected profoundly by medicine of ancient Greek world and Islamic world. In the fifth century B.C., Hippocrates, a Greek doctor analyzed many causes for infertility and presented prescription. In the end of the second century, Soranus, a doctor from the University of Ephesus tried to cover most aspects of women's reproductive problems including contraception and abortion, but did not give detailed information to the matter of infertility. Galen suggested womb facilitation to examine infertility. Dioscorides thought that infertility could resulted from drug substances and cited these substances that cause infertility (juniper, white polar, menstrual blood, etc.) Ibn-Sina (980-1037) pointed out that infertility can also happen due to men as well as women. He thought that infertility can be caused when there is something wrong with men's sperms or women's eggs. In addition, psychological factors can trigger infertility, too. In the 12th century, Averroes addressed infertility in detail and diagnosed that if women's body is too cold or too 
NAM, Jong Kuk : Social Perception of Infertility and Its Treatment in Late Medieval Italy: Margherita Datini, an Italian Merchant's Wife.

people around her seemed to rely on various types of treatment, such as professional doctors, knowledge gained from those around them, magical remedies, and religious remedies (Park, 1998: 129-30).

In the end of the 14th century in Italy, rich people living in cities and members of the noble class, like the Datinis, had help from professional doctors who graduated from college having majored in medical science. It became common for male doctors rather than midwives to treat female infertility at that time (Green, 2008: 8, 23). The doctors in charge of the Datinis were the best doctors in Europe by contemporary standards; they mainly held medical degrees from the Universities of Bologna, Padua, and Salerno. They were equipped with ancient medical knowledge, advanced Islamic medical knowledge, and up-to-date Western European medical knowledge. ${ }^{25)}$

A good number of doctors were practicing in Florence in the late 14th century. At that time, the doctor-apothecary guild (Arte dei Medici $e$ Speziali) in Florence had more than 1,000 members. This guild included not only general doctors but also surgeons, dentists, scar specialists, eye doctors, bone specialists, and specialists in calculus and urinary calculus. In addition, there were doctors employed by the municipal government to take care of the poor and doctors who treated inmates or criminals who were punished with amputation of the limbs or eye-pulling. Also, there were a few female doctors (Origo, 1986: 333). At that time, Florence

hot, having a child is difficult in his book, Colliget which is a medical encyclopedia (Aveeroës, 1574: f.62r-62v; Morice, 1995: 499-501; Park, 1998: 129-49; Green, 2008: 8, 23; Avicenna, 2014: vol.3: special pathologies, 1233-1240; Riddle, 2010: 69-70).

25) In Italy, around the late 12th century, a medical science teaching system of the same course was established. The course of the school of medicine of Bologna University was four years and that of the School of Medicine in other cities, including Florence and Perugia, was seven years. 
NAM, Jong Kuk : Social Perception of Infertility and Its Treatment in Late Medieval Italy: Margherita Datini, an Italian Merchant's Wife.

was full of professional doctors with degrees who wished for success after graduating from medical school. Some of them were from rural areas near Florence, and they went to Florence, which was at that time the major city in Europe, after earning their medical degrees to get jobs. Thus, the Datinis could be treated by many doctors (Park, 1985: 148-49).

It was in the 12th century at the University of Salerno that European medicine started to have an interest in infertility treatment in earnest. At the University of Salerno, which was a leader in 12th century medieval European medicine, most doctors and their medical texts dealt with infertility as a significant disease. ${ }^{26)}$ The Trotula (the 12 th century), a typical medical book concerning these issues which was translated into many languages after the 12th century, when it was first written in Latin, stated that infertility was curable through various methods, and mentioned physical and complexional features that were thought to cause infertility. This medical book presented certain physical features that were not conducive to pregnancy before suggesting prescriptions. According to this text, women who were too skinny or too fat, or have wombs that were too hot or too humid, would have difficulty getting pregnant. Moreover, it said that the womb could be too well-lubricated, and thus could not accept sperm. As for male infertility, testicles that were too cold or too dry make it difficult to impregnate a woman. In addition, it said that when men lack heat, sexual desire disappears, and when men lack the desire to produce semen, an erection does not happen (Green, 2001: 76-77; Cadden, 1993: 241).

26) Johannes Afflacius, Liber aureus(c.1100?), Copho, Practica(c.1120?), Johannes Platearius, Practica brevis(c.1150?), Archimattheus, Practica(between c.1150 and 1180), Bartholomeus, Practica (before 1177), Petrus Musandinus, Practica(c.1180?), Salernus, Catholica(c.1180?), Johannes de Sancto Paulo, Breviarium(before 1181) (Green, 2008: $40,86)$. 
NAM, Jong Kuk : Social Perception of Infertility and Its Treatment in Late Medieval Italy: Margherita Datini, an Italian Merchant's Wife.

Not only doctors but also theologians and the educated classes who knew Latin could read this medical book and, so, knowledge and information on infertility treatment expanded. This means that even theologians began to see infertility as a disease to be treated. The treasury of the Poor, written by Peter from Spain (later Pope John XXI), introduced 56 ways to facilitate pregnancy (Nutton, 1995: 169).

The view that certain humoral constitutions or physical defections cause infertility was generally believed by doctors at that time. William of Saliceto, a medical professor at the University of Bologna in the late 13th century, listed 12 factors that made pregnancy difficult, which consisted of humoral and physical features, in his book, Summa conservationis et curationis. He pointed out that difficulties with conceiving a child could stem from a problem with men, not just women. According to that text, it is difficult for a woman to have a child when she is too fat or too weak, when she has a complexion that is too hot or too cold, when her womb is too lubricated, or when there is inflammation or bleeding in the womb. When it comes to men, a penis that is too big or too small or is somehow defective makes pregnancy difficult. He pointed out that an overly hot or cold complexion creates an unsuitable temperature in a women's womb for having a child and advised that if the temperature could be made normal, pregnancy would be possible. Therefore, to have a child, it was good to choose a spouse with the opposite humoral constitution to one's own, and if a couple had married without knowing this, it was thought to be much easier to change a woman's humoral constitution than a man's (De Saliceto,1493: fol.i4r; Lemay, 1981: 173-74).

Interrogationes in cura sterilitatis, a medical book related to infertility which is thought to have been published in the early 14th century, also 
NAM, Jong Kuk : Social Perception of Infertility and Its Treatment in Late Medieval Italy: Margherita Datini, an Italian Merchant's Wife.

considered infertility as a medical disease. This book addressed 41 issues related to the treatment of infertility. It asked questions related to women's humors and complexions, physical features, age, marital status, whether or not they had previously experienced pregnancy or miscarriage, whether or not they had cramps, the color of menstrual blood, sexual experience and its frequency, and the color of sperm and its condition. The reason why such various questions were asked was that the infertility treatment method differed for those with different complexions or humors (Cartelle and Ingelmo, 2003: 93-94). It can be assumed from medical books such as Trotula, Summa conservationis et curationis, and Interrogationes in cura sterilitatis that the main causes of infertility at that time were thought to be humoral imbalance and problems with complexion. In this respect, medical diagnosis and judgment of infertility were based on humoral theory and complexional theory. In the 13th century in London, in a law suit seeking to cancel a marriage due to infertility, the first thing that was checked was the couple's humoral constitutions. ${ }^{27)}$ Of course, the prescriptions given for infertility were based on humoral theory and complexional theory. According to these theories, when a woman's womb was too humid, medicine to dry out the womb was prescribed, and when a woman's womb was too hot, medicine to cool down the womb was prescribed (Green, 2001: 85-87).

In the early 14th century, Montpellier medical school, which had gained international fame in the infertility field, considered infertility as a medical disease (Green, 2008: 71). In the 14th century, Montpellier medical school

27) First, David's humors were checked and then Muriel's humors were checked. When pregnancy was possible but in the case of having a miscarriage, during pregnancy, there were many cases in which both medicine and talisman were used. At that time, in Jewish and Christian medical books, using talisman together was suggested (Goldy, 2008: 142). 
NAM, Jong Kuk : Social Perception of Infertility and Its Treatment in Late Medieval Italy: Margherita Datini, an Italian Merchant's Wife.

published at least seven books addressing infertility. Arnau de Vilanova, who made a great contribution to the international fame of Montpellier medical school, thought that infertility was basically caused by physiological defects, not by devils or spells. He said in his book that obesity hinders pregnancy by suffocating sperm. To treat infertility, he prescribed medicine made of clove and garlic; this prescription was based on complexional theory, which was based on humors (McVaugh, 1993: 203-204; Morice, 1995: 501). Tractatus de steriliate mulierum, which is assumed to have been written by another doctor from Montpellier, Bernard of Gordon (d.1308), classified infertility according to the female complexion, such as too much heat, cold, humidity, or dryness, and especially focused on cases of women with infertility caused by cold or humid complexions. The author proposed many different methods of treating infertility that took constitution into account, including controlled diet, bathing, fumigation, and unguents (Bernard, 1999: 150; Green, 2008: 88).

Tractatus de sterilitate, which is assumed to be written by an anonymous doctor from Montpellier in the early 14 th century, enumerated internal and external causes of infertility. According to this medical treatise on sterility, the principal external cause was excessive intake of cold food. Internal causes included physical characteristics or imbalanced temperament, like a body that was too skinny or too fat, too young, an overly wide or lubricated uterus, abundant menstruation, suffocation and hernia of the womb, sore mouth, a lump on the womb, etc. The author discusses male infertility as well as female infertility, even while acknowledging that most of the causes stem from women (Cartelle, 1993: 72-157). ${ }^{28)}$

28) The authors of this book were not known for sure but Arnau de Vilanova, Jordan de Turre, and Raymond de Moleriis were assumed to be the writers (McVaugh, 1993: 
NAM, Jong Kuk : Social Perception of Infertility and Its Treatment in Late Medieval Italy: Margherita Datini, an Italian Merchant's Wife.

In sum, physical characteristics or defects, problems with the sexual organs of the man or the woman, and imbalanced temperaments or constitutions represent common factors thought to impede conception as put forth by medical authors. Doctors generally thought of infertility as a disease to be treated (Park, 1985: 115; de Reguardati, 1977: 112-28, 170-93). A doctor from Italy in the 15th century boasted that his treatment methods were very effective on many women with infertility, stating: "I have seen this tried through true, unquestionable experience by many women who went without offspring for a long time, one for 22 years, another for 15, another for 13, another for 11, and another for 9. And for all of these I proved this and found it to be true." Then, he explained a case of an approximately 40 year-old woman with infertility in detail. According to his explanation, this woman was very fat and had a phlegmatic complexion, so it was not easy for her to get pregnant, but, thanks to his treatment, she succeeded in having a child (Green, 2008: 250). It is not clear if infertility was really cured in that case, but there are many cases which can be used to argue that some treatments were effective. Benedetto Reguardati da Norcia, a famous doctor in Italy in the 15th century, was known for treating the wife of Francesco Sforza, the Duke of Milano (Park, 1985: 115).

The doctors who most often took care of Margherita included Lorenzo Sassoni, Lorenzo di Piero da Prato, Naddino Bovattieri, and Giovanni di Banduccio. ${ }^{29)}$ Of them, Naddino was the one who Margherita and her

204; Green, 2008: 86-89; Green, 2006: 404). However, the author mentioned that some people's infertility is caused by witch's spell and in this case, only God can cure it. Even though this book mentioned infertility caused by spell, basically, it diagnosed infertility as a disease to cure.

29) Lorenzo Sassoni got his degree from the Medical School of Padua and taught students there. Although he tried to achieve fame as a doctor, for financial problems, he gave up his dreams. In his letter to Datini of August 1403, he told that he gave up teaching in 
NAM, Jong Kuk : Social Perception of Infertility and Its Treatment in Late Medieval Italy: Margherita Datini, an Italian Merchant's Wife.

husband asked for the most advice on their infertility. How did they conclude that it was not Francesco but Margherita who was responsible for their childlessness? In the later Middle Ages, doctors could make a test to see whether the problem of infertility lies with the husband, wife, or the couple jointly. Having focused on female responsibility, the medical discussion of infertility began to include male sterility in the later Middle Ages. ${ }^{30)}$ General methods used for infertility testing in the later Middle Ages were derived from Hippocrates, Aristotle, and Avicenna. One of the simplest tests was to pour male and female urine into a pot. If there were worms in the pot ten days later, the individual was considered sterile. Otherwise, the individual was considered fertile. ${ }^{31)}$ However, in the case of Francesco and Margherita, it seemed that it was not necessary to determine which one of them was infertile because Francesco already had a child before their marriage in Avignon.

Naddino, a Prato-born doctor, moved to Avignon in the early 1380s before becoming a famous physician who treated senior clerics and eventually became the Pope's doctor (Park, 1985: 62). Even after moving to Avignon,

the medical school. With Datini's introduction, he could easily settle down in Florence relatively. He thought Datini as a person like his father for him to trust and Datini, also, treated him like his own son. Lorenzo often had a financial difficulty and borrowed money from Datini. Datini always scolded Lorenzo for his luxury and Lorenzo defended himself about it. Datini was willing to bother himself to introduce Lorenzo to many people. Datini often got prescription from Lorenzo (Park, 1985: 130, 136-37, 144; ASP, Datini, busta 1102 (11 February 1394/1395)).

30) John of Goddesdon, a famous doctor of England, said in his Rosa Anglica written in the early fourteenth century that "sterility is the failure to reproduce in a man and a woman, so that in a man it may be said to be failure to act and produce a fetus, and in a woman a failure to conceive." (Cadden, 1993: 228-229).

31) Avicenna gives an explanation of the infertility test as follows: "If a man and woman complain of infertility and they want to know which one has the problem, put both sexual fluids (sperm and egg) in water, and whichever one floats, the source of the problem is that person." (Avicenna, 2014: vol. 3, 1237; Bologne, 1988: 65-66). 
NAM, Jong Kuk : Social Perception of Infertility and Its Treatment in Late Medieval Italy: Margherita Datini, an Italian Merchant's Wife.

he continued to give medical advice to the Datinis. In a letter dated 9 June, 1385, Naddino said that hot springs may help treat Margherita's infertility (Hayez, 2001: 486). In a letter dated 11 February, 1395, he said that her infertility was caused by pain prior to menstruation. ${ }^{32)}$ He provided Francesco and Margherita with a prescription, saying that he had recently treated a patient with similar symptoms. In a letter dated 15 August 1395, he gave hope to the couple, saying that a woman who was suffering from a condition similar to that of Margherita, not only had experienced pain relief but also went on to give birth to a son and a daughter. However, the prescription enclosed with the letter is not extant (ASP, Datini, busta 1091, codice 133438; Hayez, 2001: 529-30).

It seems that the Datinis were receiving help from various doctors to treat infertility (ASP, Datini, busta 1091, codice 133437; Hayez, 2001: 527-28; Park, 1998: 129). Naddino suggested in a letter to Francesco that Margherita consult local doctors about her infertility and take medication. One of them was Giovanni di Bandocho. In a letter dated 15 August, Naddino said that replying to Francesco was delayed because information about Margherita's symptoms had been received late from Giovanni. The characteristics of the seasons were considered in the prescriptions from both Giovanni and Naddino. Naddino advised Margherita to take the medicine in April or October (Crabb, 2015: 46-47; Hayez, 2001: 529-30). The nature of the medications prescribed by these doctors is not known, but they seemed to be inefficacious. In addition, Margherita was more seriously ill than ever

32) A letter from Datini dated 9 February 1395 let Naddino know that Margherita was suffering pain prior to menstruation. Multiple acquaintances who exchanged letters with Datini testified that Margherita was suffering severe pain prior to menstruation. In a letter dated 26 April 1384, Francesco said that Margherita was very sick with pain that occurred before menstruation (ASP, Datini, busta 347, codice 3958; Crabb, 2015: 22). 
NAM, Jong Kuk : Social Perception of Infertility and Its Treatment in Late Medieval Italy: Margherita Datini, an Italian Merchant's Wife.

before in 1396 (Hayez, 2001: 531).

The prescriptions that the Datinis received from physicians to treat infertility have not been found. However, we can glean from their letters that doctors did not prescribe only one medicine to infertile women. In fact, doctors prescribed multiple drugs that took into account a number of physical characteristics, including humor, complexion, and age. Trotula of Salerno, one of the female doctors, also prescribed medication in accordance with the humoral constitutions of infertile women. ${ }^{33)}$

If the uterus was too cold, trifera magna was prescribed. This medicine seemed to be quite popular as an infertility drug in the late Middle Ages. ${ }^{34)}$ If the uterus was too humid, theodoricon euporiston and paulinum were prescribed. ${ }^{35)}$ Spikenard, which was the core component of theodoricon, was considered to have very dry and warm properties. Galbanum, the main

33) The Trotula explains that the excessive humidity of the womb suffocates the seed and the excessive heat of the womb burns the semen (Green, 2001: 85-86, 133-34; Green, 2008: 23). Trifera magna contained opium, various herbs, gums, and spices. It helps women conceive by purging the menses.

34) According to an anecdote in a medical book written in the 15 th century, a priest in Montpellier made a drug called trifera magna and a medicine mixed with Santio juice to treat infertility. Many women became pregnant thanks to his medications and he gained greater fame than any doctors in Montpellier. What Santio was like was not discovered (Green, 2008: 85-86).

35) Trifera magna(alexanders, anise, celery, celtic nard, clove, cumin, fennel, galangal. ginger, henbane, hog's fennel, honey, iris, mandrake, mugwart, opium poppy, opoponax, pepper, spikenard, storax, sweet basil, sweet flag, wild carrot, zedoary), theodoricon euporiston (agaric, aloe, ammoniacum, asafetida, bdellium, birthwort, cabbage, camel grass, cassia, castoreum, cinnamon, colocynth, costmary, dodder, felwort, ginger, hazelwort, scammony, mastic gum, myrobalan, myrrh, opium poppy, opoponax, parsley, pepper, polypody, poppy, rhubarb, saffron, serapinum, silphium, spikenard, squill, sweet flag, wall germander, wine, wormwood ), paulinum (agaric, aloe, ammoniacum, balm, balsam tree, bdellium, cleavers, coral, costmary, frankincense, galbanum, honey, scammony, marking nut, mastic gum, myrrh, oppium poppy, opopnax, oriental crocus, saffron, serapinum, storax, turpentine) (Green, 2001: 133-34, 138-64; Mcvaugh and Ferre, 2000: 82, 116, 144). 
NAM, Jong Kuk : Social Perception of Infertility and Its Treatment in Late Medieval Italy: Margherita Datini, an Italian Merchant's Wife.

constituent of paulinum, was considered to have very dry properties. ${ }^{36}$ These drugs were used to treat other diseases as well as infertility. In this regard, the core of infertility treatment was to make an infertile woman healthy enough so that she could become pregnant by improving any imbalance in her humors (Morice, 1995: 501).

Margherita depended on folk remedies as well as doctors. In a letter dated 7 September, 1393, Margherita's sister Francesca said that many women there were pregnant, including the wife of Tommaso Solderini, thanks to a poultice (impiastro) made by the wife of Nofri di Messer Lapo Arnolfi. Francesca even seemed to have asked the wife of Nofri di Messer Lapo Arnolfi to make one. She was told that this poultice, which was effective in winter and was supposed to be applied to the stomach, smelled so awful that Margherita needed permission from Francesco to use it. In a letter to her husband dated 16 September, 1393, Francesca passed on this information to her husband and also wrote that the poultice was made considering the health condition of each woman, and that it did not cost very much (e di pichola spesa). ${ }^{37)}$ The letter did not mention what materials were used to make the poultice. It is thought that nettle, mandrake, and artemisia, which were widely used to make poultices for treating infertility, were used (Morice, 1995: 501). One of the folkloric methods used by ordinary people in England was to apply wool soaked in ass's milk to the woman's navel, or to have her bathe and drink a potion (Cadden, 1993:

36) Le livre des simples medecines says that spikenard is hot in the first degree and dry in the second degree and galbanum is hot in the third degree and moist in the first degree, while Tabula mentions that spikenard and galbanum are hot and dry in the third degree (Ospomer-Halleux, 1984: 165-66, 245-246; Mcvaugh and Ferre, 2000: 82, 144).

37) 〈Qui son grosse di molte donne tra llequali e grossa la moglie di messer Tomaso Solderini.) (ASP, Datini, busta 1089.02, codice 6000576-6000577; Crabb, 2015: 46-47; Park, 1998: 129; Origo, 1986: 167). 
NAM, Jong Kuk : Social Perception of Infertility and Its Treatment in Late Medieval Italy: Margherita Datini, an Italian Merchant's Wife.

239).

As illustrated by Margherita's reliance on folk remedies, people at the time were willing to go to any lengths to cure infertility. The following anecdote illustrates this point. According to a medical book from 15 th century France, there was a priest who cured infertility and made infertile women pregnant in Montpellier. He treated many infertile women using two drugs that he created and then gained greater fame than any other doctor in Montpellier. A number of women reportedly came to him to get those two drugs and became pregnant (Green, 2008: 85).

Margherita also went to hot springs for the purpose of treating infertility. At the time, people thought that hot springs are good for getting pregnant as they would help women recover their strength. In a letter dated 20 May, 1384, Niccolo Tecchini wrote that the Datinis came back healthy from the hot springs and he heard the encouraging news that Margherita would be able to be pregnant thanks to the hot springs. ${ }^{38)}$ In a letter dated 20 June, 1384, Jacopo del Nero di Vanni, a medicine dealer, said that the Datinis came back from the hot springs and he heard that Margherita seemed to be pregnant. ${ }^{39)}$ However, Naddino wrote that a more careful approach was needed for the hot springs to be effective. In a letter dated 9 June, 1385, he asked whether the hot springs were beneficial to Datini's liver and Margherita's infertility. He said that hot springs may or may not have

38) 〈Vo dite che da alchimi venuti dal bagno avete sentito che Franciescho e lla margherita stanno bene piaciemi lo do nabbia I ddio e llui priegho de fare grazia di ritornare con buon punto e chon disposizione davere de figliuoli.) (ASP, Datini, busta 1113, codice 133866. Letter from Niccolò dell'Ammannato to Monte Angiolini (from Florence to Prato).)

39) 〈Franciescho nostro di poi tornato dal bagno e gli sano e monna Margherita grossa ieri giunse qui.) (ASP, Datini, busta 347, codice 183. Letter from Iacopo del Nero di Vanni to Monte Angiolini (from Avignon to Prato)). 
NAM, Jong Kuk : Social Perception of Infertility and Its Treatment in Late Medieval Italy: Margherita Datini, an Italian Merchant's Wife.

been good for the couple's health, depending on their composition. He added that it was difficult to give correct advice because he did not know the composition of the hot springs (Hayez, 2001: 486).

Acquaintances of Francesco and Margherita suggested magical treatment methods. In a letter dated 23 April, 1395, Tecchini suggested something unusual to Francesco. It was to let a male virgin put a belt with spells written on it on Margherita's stomach. Sometimes she had to call the Father and the Virgin three times, praise God, and recite the Holy Trinity and St. Caterina when taking the medicine. These prayers were written on the belt (ASP, Datini, busta 1103, codice 134071; Crabb, 2015: 46; Origo, 1986: 334-37). Other than the above examples, various types of magical therapies were used to treat infertility. In some regions, infertile women were told to drink holy water. There was a superstition that one would get pregnant if one buried an egg near a cathedral and dug it out eight days later to eat it. There was also a belief that a woman could get pregnant after rubbing her stomach on a sacred stone (Morice, 1995: 502).

Doctors were also relying on magical methods in the later Middle Ages. Since antiquity, scientists and medical writers believed that magic was effective against some illnesses, including infertility and impotence, and these types of beliefs continued into the later Middle Ages. ${ }^{40)}$ Certain medieval doctors prescribed different amulets to allow infertile men and women to ward off the devil. Such doctors required their patients to memorize prayers or spells when they prescribed drugs. Some late medieval medical writers suggested magical remedies to cure diseases with magical

40) Pliny said that "When word at the girdle by infertile woman the stone (ammonites) is said to induce fertility and bring forth happy childbirths." (Duffin, Moody, and GardnerThorpe, 2013: 53). 
NAM, Jong Kuk : Social Perception of Infertility and Its Treatment in Late Medieval Italy: Margherita Datini, an Italian Merchant's Wife.

origins or demonic illnesses, particularly male impotence, or to expel demons. In the eleventh century, Constantine the African devoted a chapter of his medical book to impotence resulting from witchcraft and offered a particular magical remedy to combat spells that prevented couples from having intercourse (Marti-Iban̆ez, 1960: 146-147; Grant, 1974: 767-768). But, in general, late medieval doctors considered those magical remedies to be irrational and bad practice. Many more medical writers preferred to focus on the physical causes of infertility. In this regard, we can say that demons occupied only a marginal place in late medieval medicine. ${ }^{41)}$ In addition, use of these sorts of magical remedies was punishable. In 1326, a doctor named Antoni Imbert working in a southern French city was accused of offering fraudulent, diabolical, and expensive cures to infertile women and impotent men. According to the prosecution, he used drugs, hot springs, potions, lies, evil ways, and witchcraft (arte falsa et magica, et medicis, balneis et potionibus et aliis dolose utendo) (Shatzmiller and Lavoie, 1984: 135; Green, 2008: 86; Green, 2006: 403; Cadden, 1993: 231).

Margherita, who was a devout Christian, incessantly urged her husband to give up mundane business and resort to eternal God and rely on religion to treat infertility. Although the practice is not well described in the Datini documents, many people prayed to saints, particularly female saints, to make them pregnant. Preachers encouraged infertile women to pray to saints to ask for children, and the Church emphasized that the saints were

41) A French book of the thirteenth century, Le Dialogue de Placides et Timeo, said that "De rechief, les anchiens maintiennent que l'on poeult malefiier homme et femme par herbes prinses en certaine saison, ou par plusieurs sorceries, par telle fachon que homme ne pourroit jamais engenrer ne femme conepvoir. Maiz toutez tells oeuvres sont choses dyabolique et contre bonnes meurs. Et il tient à homme ou à femme se ilz ne ont lignie." (Bologne, 1988: 58-59). 
NAM, Jong Kuk : Social Perception of Infertility and Its Treatment in Late Medieval Italy: Margherita Datini, an Italian Merchant' s Wife.

likely to respond positively to the requests of devout Christians. Women turned to, first of all, Saint Anne, Mary's mother, and Mary the Virgin, and then to other saints. Infertile women applied earnestly to Saint Anne, the patron saint of barren women, because she had conceived a child through divine intervention. The Virgin Mary represented the ultimate symbol of motherhood, and Saint Margaret the Virgin was the patron saint of pregnant woman. Infertile women applied to these saints, saying that the Virgin Mary conceived Jesus Christ in spite of her infertility and that Elisabeth conceived John the Baptist, a precursor of Jesus Christ, despite her infertility." ${ }^{42)}$ According to a document from the early 14th century, infertile women in Hereford, England, gave offerings to St. Thomas Cantelupe in exchange for curing infertility (Gilchrist, 2012: 134). The fact that people asked God or saints for help curing infertility was partly related to the notion that infertility was a punishment wrought by God for sins or the conduct of the devil. Only God could forgive this punishment and cure infertility caused by the devil. ${ }^{43)}$

The story of Margherita's infertility proves that the distinction among religion, medicine, magic and folkloric remedies was often difficult to draw. Margherita tried all the methods available to her to cure her infertility over a long period of time.

42) Daphna Oren-Magidor makes a remark that protestant preachers encouraged infertile women to pray directly to God instead of saints (Oren-Magidor, 2015: 87-88; Bologne, 1988: 111-113; Lunenfeld and Elder, 2005: 129-31).

43) One medical text argued that only God was able to cure infertility if the spell of a witch caused it (McVaugh, 1993: 204). 
NAM, Jong Kuk : Social Perception of Infertility and Its Treatment in Late Medieval Italy: Margherita Datini, an Italian Merchant's Wife.

\section{Conclusion}

In the end, Margherita did not succeed in overcoming her infertility and never had a child, even though she tried diverse methods, such as medical treatments, folkloric recipes, magical remedies, religious prayers, etc. Likewise, it seems that medieval Christian Europe failed to find solutions to cure infertility. Richard the English admitted frankly, after many years of experience attempting to treat infertile woman, that female infertility was a disease more often incurable than curable. Innumerable pharmacopoeia prescribed by medieval doctors were not effective in curing this troublesome disease (Bologne, 1988: 59).

The analysis of Margherita's infertility does not give a definite answer to the question of what the common perception and attitudes of ordinary people towards infertility were in the later Middle Ages. That is because she relied on diverse methods of treating infertility, from witchcraft and religion to medications. In addition, among the various infertility treatments discussed above, it was difficult to determine which one Margherita thought was the best. In reality, both the general public and doctors relied on diverse methods of treating infertility, such as witchcraft and religion as well as medications (Shatzmiller and Lavoie, 1984: 135). People's perspectives and attitudes towards infertility were very complicated.

However, what is evident is that Margherita and those around her did not consider infertility as a curse or punishment by God for her sins. It seems that they did not share the extreme belief that infertility was caused by the devil and witchcraft. Generally, Margherita and those around her regarded infertility as a disease which might be, though was not always, curable through medical, religious, magical, folkloric or mysterious methods. 
NAM, Jong Kuk : Social Perception of Infertility and Its Treatment in Late Medieval Italy: Margherita Datini, an Italian Merchant' s Wife.

Therefore, Margherita and her husband continued to attempt to overcome this disease for a long time, trying several different methods of solving the problem. We suggest that the ordinary, common perception of infertility in Medieval Europe was located somewhere between the religious view of it as a curse wrought by God or the devil's diablerie and the medical view of it as a disease to be treated.

We can also add that medieval European society did not succeed in finding a conclusive and definite treatment for infertility. As Jean Claude Bologne quite rightly suggested, the diversity of treatments prescribed by doctors which were not decisively effective attests to the helplessness of doctors in the face of this rebellious disease (Bologne, 1988: 137).

Keywords: Margherita Datini, Francesco Datini, infertility, Medieval Europe, Florence, Prato, medical books, devil, disease, social perception 
NAM, Jong Kuk : Social Perception of Infertility and Its Treatment in Late Medieval Italy: Margherita Datini, an Italian Merchant's Wife.

\section{참고문헌 REFERENCES}

〈Primary Sources〉

Manuscripts

ASP, Datini, busta 347, codice 183, 3958.

ASP, Datini, busta 1089.02, codice 600576, 600577.

ASP, Datini, busta 1090, codice 1402925, 1402927, 1402928, 1402939.

ASP, Datini, busta 1091, codice 113437, 113438.

ASP, Datini, busta 1102 (11 February 1394/1395).

ASP, Datini, busta 1103, codice 133344, 133345, 113347, 113348, 134071.

ASP, Datini, busta 1113, codice 133866.

ASP, Datini, codice 315535.

〈Published Primary Sources〉

Africanus, Constantinus, Liber de coitu: El tratado de andrologia de Constantino el Africano, edited and translated by Enrique Montero Cartelle (Santiago de Compostela: Universidad de Santiago, 1983).

Anglicus, Johannes, Rosa Anglica practica medicine (Venice: Bonetus Locatellus, 1516).

Aveeroës, Colliget (Venezia, 1574).

Avicenna, The Canon of medicine, translated by Peyman Adeli Sardo (Chicago: Great Books on the Islamic World, 2014).

Bernard, Pseudo, Tractatus de sterilitate mulierum, ed. Montero Cartelle (Valladolid: Universidad de Valladolid, 1999).

Cartelle, Enrique Montero ed., Tractatus de Sterilitate : anónimo de Montpellier (s. XIV) (Valladolid: Universidad de Valladolid, 1993).

Cartelle, Enrique Montero and Ingelmo, Maria Cruz Herrero eds., "Las Interrogationes in Cura Sterilitatis en el marco de la literature médica medieval," Faventia 25 (2003), pp. 85-97.

Datini, Margherita, Letters to Francesco Datini, trans. Carolyn James and Antonio Pagliaro (Toronto: Centre for reformation and Renaissance studies, 2012).

De Saliceto, Guilielmus, Summa conservationis et curationis (Venezia, 1493).

Gratian, Corpus Juris Canonici, edited by Emil Friedberg (Austria: Akademische Druck-u. Verlagsanstalt, 1959). 
NAM, Jong Kuk : Social Perception of Infertility and Its Treatment in Late Medieval Italy: Margherita Datini, an Italian Merchant' s Wife.

Green, Monica H. ed. and trans., The Trotula. An English translation of the medieval compendium of women's medicine (Philadelphia: University of Pennsylvania Press, 2001).

Kramer, Heinrich and Sprenger, James, The Malleus Maleficarum, ed. and trans. Montague Summers (New York: Dover Publications, 1971).

McVaugh, M. and Ferre, L., The Tabula antiodotarii of Armengaud Blaise and its hebrew translation (Philadelphia: American Philosophical Society, 2000).

Ospomer-Halleux, C. ed., Livre des simples medicine. Codex Bruxellenis IV. 1024. A 15th-century French herbal (Antwerp: De Schutter, 1984).

Parrado, Pedro Conde, Cartelle, Enrique Montero, and Ingelmo, Maria Cruz Herrero eds., Tractatus de Conceptu/Tractatus de Sterilitate Mulierum (Valladolid: Universidad de Valladolid, 1999).

〈Secondary Sources〉

Austriaco, Pier Giorgio, Biomedicine and Beatitude: an introduction to catholic bioethics (Washington, D.C.: The Catholic University of America Press, 2011).

Baldwin, J. W., The language of sex: five voices from Northern France around 1200 (Chicago and London: The University of Chicago Press, 1994).

Bologne, Jean Claude, La naissance interdite: stérilité, avortement, contraception au Moyen Age (Paris: Olivier Orban, 1988).

Byrne, Joseph P., "Crafting the merchant wife's tale: historians and the domestic rhetoric in the letters of Margherita Datini," Journal of the Georgia Association of Historians 16 (1996), pp. 1-17.

Byrne, Joseph P. and Congdon, Eleanor A., "Mothering in the Casa Datini," Journal of Medieval History 25 (1999), pp. 35-56.

Cadden, Joan Cadden, Meanings of sex difference in the middle Ages (Cambridge: Cambridge University Press, 1993).

Crabb, Ann, The merchant of Prato's wife: Margherita Datini and her world 1360-1423 (Ann Arbor: University of Michigan Press, 2015).

Crabb, Ann, "Ne pas être mère: l'autodéfense d'une Florentine vers 1400," Clio. Histoire, femmes et sociétés 21 (2005), pp. 150-161.

De Reguardati, Fausto M., Benedetto de' Reguardati da Norcia (Trieste: Lint, 1977).

Echenverria, Euardo J., "In the beginning....": a theology of the body (Eugene: 
NAM, Jong Kuk : Social Perception of Infertility and Its Treatment in Late Medieval Italy: Margherita Datini, an Italian Merchant's Wife.

Pickwick Publications, 2011).

Duffin, C. J. Duffin, Moddy, R. T. J., and Gardner-Thorpe, G. eds., A History of Geology and Medicine (London: The Geological Society, 2013).

Evans, Jennifer Evans, “Bewitched in Their Privities': Medical Responses to Infertility Witchcraft in Early Modern England,” Societas Magica 27 (2012), pp. 1-3.

Geaman, Kristen, "Power in the Uterus: Negotiating Royal Infertility in England, 13281471,” PhD diss., University of Southern California, 2013.

Gilchrist, Roberta, Medieval life: archaeology and the life course (Woodbridge: Boydell Press, 2012).

Goldy, Charlotte Newman, "A thirteenth-century Anglo-Jewish woman crossing boundaries: visible and invisible," Journal of Medieval History 34 (2008), pp. 130-145.

Grant, Edward ed., A Source book in Medieval Science (Massachusetts: Harvard University Press, 1974).

Greene, Monica, Making Women's Medicine Masculine: The Rise of Male Authority in Premodern Gynaecology (Oxford: Oxford University Press, 2008).

Green, Monica, "Infertility," M. Schaus ed., Women and gender in Medieval Europe: an encyclopedia (New York and London: Routledge, 2006), pp. 403-404.

Hayez, J., "Expérience de migrant et pratique de l'amitié dans la correspondance de maestro Naddino d'Aldobrandino Bovattieri médecin toscan d'Avignon (13851407)," Bibliothèque d'Ecole des Chartes 159 (2001), pp.413-539.

James, Carolyn, “A Woman's work in a man's world: the letters of Margherita Datini (1384-1410)," Giampiero Nigro ed., Francesco di Marco Datini: the man the merchant (Firenze: Firenze University Press, 2010), pp. 53-72.

Lemay, H. R., "Human sexuality in Twelfth- through Fifteenth century scientific writings," V. L. Bullough and J. Brundage eds., Sexual practice and the medieval church (New York: Prometheus Book, 1982), pp. 187-205.

Lemay, H. R., “William of Saliceto on human sexuality," Viator 12 (1981), pp.165-181.

Lindgren, Amy, "The Wandering Womb and the Peripheral Penis: Gender and the Fertile body in Late Medieval Infertility Treatises," PhD diss, University of California, 2005.

Longenbach, Erica M., "A fountain bewitched: gender, sin, and propaganda in the massa marittima mural," PhD diss., University of North Carolina, 2008. 
NAM, Jong Kuk : Social Perception of Infertility and Its Treatment in Late Medieval Italy: Margherita Datini, an Italian Merchant's Wife.

Lunenfeld, Bruno and Elder, Kay, "Historical perspectives in the management of fertility and the use of gonadotropins," Peter R. Brinsden ed., Textbook of In vitro fertilization and assisted reproduction (Oxon: Taylor \& Francis, 2005), pp. 12931.

Marti-Ibaňez, Felix ed., Henry E. Sigerist on the history of medicine (New York: MD Publications, 1960).

McVaugh, Michael R., Medicine before the plague: practioners and their patients in the crown of Aragon 1285-1345 (Cambridge: Cambridge University Press, 1993).

Morice, Philippe et al., "History of infertility," Human Reproduction Update 1 (1995), pp. 497-504.

Noonan, J. T., Contraception. A history of its treatment by the catholic theologians and canonists (Cambridge: The Belknap Press of Harvard University Press, 1965).

Nutton, Vivian, "Medicine in Medieval Western Europe, 100-1500," L. I. Conrad et al. ed., The Western medical tradition 800 BC to AD 1800 (Cambridge: Cambridge University Press, 1995), pp. 139-206.

Oren-Maghidor, Daphna, "From Anne to Hannah: religious views of infertility in PostReformation England," Journal of Women’s History 27 (2015), pp. 86-108.

Oren-Magidor, Daphna and Rider, Catherine, "Introduction: infertility in Medieval and Early Modern Medicine," Social History of Medicine (2016), pp. 1-13.

Origo, Iris, The Merchant of Prato: Francesco di Marco Datini (Boston: Nonpareil Books, 1986).

Park, Katharine, "Medicine and magic: the healing arts," Judith C. Brown and Robert C. Davis eds., Gender and society in Renaissance Italy (London and New York, 1998), pp. 129-149

Park, Katharine, Doctors and medicine in Early Renaissance Florence (Princeton, 1985).

Rider, Catherine, "Men and infertility in Late Medieval English Medicine," Social History of Medicine (2016), pp. 1-26.

Riddle, John M. Riddle, Goddesses, elixirs, and witches: plants and sexuality throughout human history (New York: Palgrave Macmillan, 2010).

Rooy, H. F. van, "Fertility as blessing and infertility as curse in the ancient near East and the Old Testament," Anthony Bonano ed., Archaeology and fertility cult in the ancient Mediterranean (Amsterdam: B.R. Gruner Publishing Co., 1986), pp. 225-235. 
NAM, Jong Kuk : Social Perception of Infertility and Its Treatment in Late Medieval Italy: Margherita Datini, an Italian Merchant's Wife.

Schuller, Michelle, “L’Exil domestique de Margherita Datini L'histoire singulière d'un couple," Arzanà 16-17 (2013), pp. 303-322.

Shatzmiller, J. and Lavoie, R., "Médecine et gynécologie au Moyen Age: un exemple provençal," Razo: Cahiers du Centre d'Etudes Médiévale de Nice 4 (1984), pp. 132-143.

Taylor, Nathaniel L., "Women and wills: sterility and testacy in Catalonia in the eleventh and twelfth centuries," Medieval Encounters 12 (2006), pp. 87-96.

투고일: 2016. 10. 12 심사일: 2016. 10. 29 게재확정일: 2016. 11. 22 


\title{
Social Perception of Infertility and Its Treatment in Late Medieval Italy: Margherita Datini, an Italian Merchant's Wife
}

\author{
NAM, Jong Kuk \\ Department of History, Ewha Womans University, Seoul, Korea
}

Because the perception of infertility in medieval Europe ranged from the extremely religious view of it as a malediction of God or the devil's work, to the reasonable medical conception of it as a sort of disease to treat, it is very difficult to determine the general attitudes of ordinary people towards infertility. This article seeks to elucidate the common social perception of infertility and its treatment in late medieval Europe by analyzing the case of Margherita Datini, an Italian merchant's wife who lived in the 1400s. It relies heavily on the documents left by her and her husband, Francesco Datini; the couple left many records, including letters of correspondence between them. Margherita and those around her regarded infertility not as the devil's curse or a punishment by God but as a disease that can be cured. Margherita and her husband, Francesco, tried hard to cure their infertility. They received treatment and prescriptions from several doctors

\footnotetext{
* Department of History, Ewha Womans University

E-mail: namjk0513@ewha.ac.kr
} 
NAM, Jong Kuk : Social Perception of Infertility and Its Treatment in Late Medieval Italy: Margherita Datini, an Italian Merchant's Wife.

while also relying on folk remedies, religious therapies, and even magical remedies. The comparative analysis of Datini documents, medical books, and theoretical treatises or prescriptive essays by clerics suggests that the general perception of infertility in medieval Europe was located between the extremely religious and modern medical conceptions of it.

Keywords: Margherita Datini, Francesco Datini, infertility, Medieval Europe, Florence, Prato, medical books, God, devil, disease, social perception 